\title{
NORMAL, MUMLU (WAXY) VE YÜKSEK AMİLOZLU NİŞASTALAR VE GIDALARDAKİ FONKSİYONEL ÖZELLİKLERİ
}

\author{
Erkan Yalçın $^{1 *}$, M. Tuğrul Masatcıoğlu ${ }^{2}$, Betül Cındık ${ }^{1}$ \\ ${ }^{1}$ Bolu Abant İzzet Baysal Üniversitesi, Gıda Mühendisliği Bölümü, Bolu, Türkiye \\ ${ }^{2}$ Hatay Mustafa Kemal Üniversitesi, Gıda Mühendisliği Bölümü, Hatay, Türkiye
}

Geliş / Received: 09.10.2020; Kabul / Accepted: 25.11.2020; Online bask1 / Published online: 04.12.2020

Yalçın, E., Masatcıŏ̆lu, M.T., Cındık, B. (2020). Normal, mumlu (waxy) ve yüksek amilozlu nişastalar ve g1dalardaki fonksiyonel özellikleri. GIDA (2020) 45(6)1261-1271 doi: 10.15237/gida.GD20117

Yalçn, E., Masatcooğlu, M.T., Cindık, B. (2020). Normal, waxy and high-amylose starches and their functional properties in foods. GID A (2020) 45(6)1261-1271 doi: 10.15237/gida.GD20117

\section{ÖZ}

Nişasta, amiloz ve amilopektin polisakkaritlerinden meydana gelmiş, gıdalara yapısal özellikler kazandıran, beslenmemizde enerji ihtiyacımızın önemli bir kısmını karșılayan, sindirilebilir bir karbonhidrattır. Nişastaların farklı amiloz/amilopektin oranları; granüler yapıda, fiziko-kimyasal özelliklerde ve son ürün kalitesinde bazı farklılıklara sebep olmaktadır. Genellikle, normal, mumlu ve yüksek amilozlu nişastalarda amiloz/amilopektin oranı sırasıyla 25/75, 0/100 ve 70/30 olarak belirtilmiştir. Doğal nişastaların gıdalardaki kullanımı sınırlı kalmaktadır. Normal nişasta hızlı sindirilebilir olması sebebiyle gıdanın glisemik indeksini yükseltir. Yüksek amilozlu tahıl nişastaları, enzime dirençli nişasta üretiminde kullanılmaktadır. Amiloz içeriği arttıkça nişasta sindirimi de yavaşlamaktadır. Gıdaların beslenme kalitesinin farklı yapısal ve fonksiyonel Özellikteki nişasta tipleri kullanılarak artırılması, beslenmeye bağlı kronik hastalıkları azaltmada etkili olabileceği belirtilmektedir. Beslenmedeki önemi dışında, nişastanın gıdalarda çirişlenme, su tutma, geçirgenlik, stabilizatör ve kıvam artırıcı özelliklerinin iyileştirilebilmesi için farklı tipte nişastalara ihtiyaç duyulmaktadır.

Anahtar kelimeler: Normal nişasta, mumlu nişasta, yüksek amilozlu nişasta, fonksiyonel özellikler, çirişlenme özellikleri, nişasta sindirilebilirliği, enzime dirençli nişasta

\section{NORMAL, WAXY AND HIGH-AMYLOSE STARCHES AND THEIR FUNCTIONAL PROPERTIES IN FOODS}

\begin{abstract}
Starch, which is consisting of amylose and amylopectin polysaccharides, gives textural properties to food products, and provides the most of the energy in our nutrition, and is a digestible carbohydrate. Different amylose/amylopectin ratios in starch structure cause some distinctions in granular structure, physicochemical properties, and final product quality. Generally, amylose/amylopectin ratios of normal, waxy, and high amylose starches are indicated as 25/75, 0/100 and 70/30, respectively. The utilization of native starches in foods is limited. Normal starch, which is rapidly digestible, raises the glycaemic index of food. High-amylose cereal starches are used in the production of enzyme resistant starch. An increase in amylose content slows down the starch digestibility. An
\end{abstract}

\footnotetext{
${ }^{*}$ Yazışmalardan sorumlu yazar/Corresponding author:

: yalcin_e@ibu.edu.tr Ð: (+90) 3742534640 / 4832

且: (+90) 3742534558
}

Erkan Yalçın; ORCID no: 0000-0002-7417-9088

M. Tuğrul Masatcıoğlu; ORCID no: 0000-0002-2583-8796

Betül Cındık; ORCID no: 0000-0001-9765-9861 
increase in nutritional quality of foods using starch types having different structural and functional properties exhibits a great impact on decreasing chronic diseases depended on nutrition. In addition to nutritional importance, to improve the pasting, water holding, transmittance, stabilization, and thickening properties of starch in foods, the different starch types are required.

Keywords: Normal starch, waxy starch, high-amylose starch, functional properties, pasting properties, starch digestibility, enzyme resistant starch

\section{GİRIŞ}

Nişasta, günlük kalorinin \%75'inden fazlasını sağlar ve yem, biyo-yakıt ve şeker şurupları gibi birçok endüstride önemli bir hammaddedir. Nişastanın, tahıllar, baklagiller ve kök bitkilerinde başlıca depo karbonhidrat olduğu bildirilmiştir. Amiloz ve amilopektin olarak adlandirilan sirasiyla doğrusal ve dallanmıs glukan polimerlerinden oluşan nişastanın, granüller şeklinde meydana geldiği belirtilmiştir. Amiloz ve amilopektin, granül içinde yar1-kristal formda, suda çözünmeyen tabakalar halinde bulunmaktadır. Amilozun, $\alpha-1,4$ glikozidik bağlarıly bağlı 20005000 adet D-glukopiranozil polimerinden meydana gelen ve \%0.2-0.5 oraninda dallanma gösteren bir polisakkarit olduğu belirtilmiştir. Amilopektin ise yaklaşı 10000 polimerizasyon derecesine (PD) sahip, \%5-6 oranında $\alpha-1,6$ glikozidik bağlarılla bağlı dallanma noktaları ve yüzlerce kısa $\alpha-1,4$ bağlarılla bağlı $D$ glukopiranozil birimlerinden oluşan bir polisakkarit olarak tanımlanmıştır. Gıdalardaki normal nişastaların amiloz ve amilopektin oranları sırasiyla, \%25-28 ve \%72-75 olarak belirtilmiştir. Yüksek amilozlu (amilotip) nişastalar \%85'e kadar amiloz içerirken, mumlu (waxy) nişastalar $\% 0$ amilozdan yaklassık \%9'a (mumlu arpa) kadar amiloz içerebilmektedir. Doğal nişastalar, sıcaklık ve $\mathrm{pH}$ değişimlerine karşı kararsız olduklarından ve dengesiz jel stabilitesi gösterdiklerinden endüstriyel kullanım için uygun olmadığı ifade edilmiştir. $\mathrm{Bu}$ sebeple, doğal nişastalar, fonksiyonel özelliklerini iyileştirmek için çeşitli yöntemler ile modifiye edilmektedir (Hung vd., 2006; Ahmed vd., 2016; Shevkani vd., 2017; Precha-Atsawanan vd., 2018; Yoo vd., 2018; Samarakoon vd., 2020). Gida endüstrisinin kimyasal yöntemlerle modifiye edilmiş nişasta kullanımını azaltmak için çeşitli nişasta modifikasyonları üzerinde çalısılmaktadır. Buna göre, yüksek nemde (\%40-76) ve jelatinizasyon sıcaklığının altında fakat camsı geçiş sıcaklığının üstünde yapılan yumuşatma (tavlama) yönteminin, nişastanın granül yapısını değiştirmeden fiziko-kimyasal özelliklerini iyileştirebilen bir modifikasyon olduğu belirtilmiştir. Kesikli veya kesiksiz yapılan bu yöntemde, nişastanın molekül ağırlı̆̆1 (amiloz/amilopektin oranı), mikroskobik kristal yapıs1, fiziko-kimyasal özellikleri ve in vitro sindirilebilirliğinin değiştirilebildiği ifade edilmiştir (Samarakoon vd., 2020; Su vd., 2020). Doğal pirinç ve diğer nişastaların teknolojik eksikliklerinin üstesinden gelmenin alternatif bir yolu da, doğal nişastalara hidrokolloidlerin eklenmesidir (Lee ve Kim, 2020).

\section{MUMLU VE YÜKSEK AMİLOZLU NİŞASTALARIN SENTEZİ}

Amiloz, waxy veya wx enzimi olarak da bilinen granüle bağli nişasta sentetaz enzimi I (granulebound starch synthase I-GBSSI) tarafindan sentezlenirken; amilopektin, çözünür nişasta sentetaz enzimi (soluble starch synthase-SSIIa), dallanmiş nişastadan sorumlu enzim (starch branching ensyme-SBE) ve nişastanın dallanma noktaların kıran enzim (starch debranched ensyme$D B E)$ tarafindan sentezlenmektedir. Ekmeklik buğday hegzaploid yani A, B ve D genomlanna sahip bir tahıldır. Her üç genomdan geçersiz/boş (null) sentezlenen GBSSI genleri (GBSSI-A1, GBSSI-B1 ve GBSSI-D1) amiloz sentezini durdururken amilopektin sentezini artırmaktadır. Tam tersine yine her üç genomdan geçersiz/boş sentezlenen SSIIa genleri (SSIIa-A1, SSIIa-B1 ve SSIIa-D1) ise amilopektin sentezini durdururken amiloz miktarını oransal olarak artırdığı ifade edilmiştir. Her iki gendeki (GBSSI ve SSIIa) geçersiz/boş mutasyonlar sonucu "tatlı buğday" olarak adlandırılan yüksek şekerli (özellikle yüksek maltozlu) çeşitlerin meydana geldiği bildirilmiştir. Tahıllarda, nişasta dallanma noktalanından sorumlu enzimin üç adet izozim formu (I, IIa ve IIb) keşfedilmiştir. Bunlardan nişastada dallanma noktalarından sorumlu enzimlerin (IIa ve IIb) RNA üzerindeki gen dizilimlerinin baskılanması 
ile amiloz içeriğinin buğdayda \%74'e kadar yükseltilebileceği saptanmıştır (Inokuma vd., 2016; Shevkani vd., 2017).

Mumlu (waxy) özellik, waxy lokusundaki granüle bağlı nişasta sentetazının (GBSSI enzimi) sentezi sirasindaki mutasyonlar sonucunda ortaya çıkmaktadır. Sonuç olarak waxy geni, GBSSI enzimini kodlayan genlerdeki doğal veya doğal olmayan genetik mutasyonlardan kaynaklanmaktadır ve pirinç, arpa, misır ve buğday dâhil birçok tahılda tanımlanmıştır (Graybosch vd., 2016; Fleischman vd., 2016; Svihus vd., 2005). Mumlu buğday ilk olarak 1994 yllında geleneksel yetiştirme tekniği kullanılarak geliştirilmiştir. Mumlu buğdayda, amiloz sentezinden sorumlu granüle bağlı nişasta sentetaz I (GBSSI) enziminin baskilanması sayesinde endospermde saptanabilir amiloz bulunmadığ1 görülmüştür (Hsieh vd., 2019). Mumlu nişasta neredeyse sadece $\alpha$-(1,6)-glikozidik bağlan ile oldukça dallanmış bir yapı gösterip, çok az düzeyde kisa $\alpha$-(1,4)-D-glikopiranozil zincirleri içeren, yüksek molekül ağırlıklı ve yoğun kristal yapilı bir polisakkarittir (Šárka ve Dvořáček, 2017).

\section{MUMLU VE YÜKSEK AMİLOZLU Nİ̧̧ASTALARIN YAPISAL ÖZELLIKKLERİ}

Nişasta granülü, amiloz ve amilopektin polisakkaritlerinden meydana gelmiş yar1-kristal bir makromoleküldür. Nişasta granülü katmanlı tabakalardan meydana gelmiştir (Hung vd., 2006). Nişasta; değirmen, mikser, durultucu ve filtrasyonlu santrifüj, hidrosiklonlar ve siklonlar, vakum filtreleri, akışkan kurutucular ve elekler gibi birçok makine ve ekipmanı içeren bir teknolojiyle izole edilmektedir (Šárka ve Dvořáček, 2017). Nişasta granüllerinin boyutu, şekli, yapısı ve sayısı nişasta izolasyonu için çok önemli kriterlerdir ve nişasta tipine göre farklılık gösterir. Botanik açıdan farklı spesifik şekil, boyut ve yüzeylere (pürüzsüz veya pürüzlü) sahip nişasta granüllerinin fonksiyonel özellikleri ve sindirimi de farklilık gösterir (Magallanes-Cruz vd., 2017; Su vd., 2020).

Nişastadaki amilozun amilopektine oranı, amiloz ve amilopektin yapıları, bu iki polimerin düzenlenme şekli, bulunduğu yer ve diğer moleküller ile etkileşimleri nişastanın fizikokimyasal ve fonksiyonel özelliklerini belirlemektedir. Amilozun amilopektine oran1, hamurun özelliklerini ve son ürün kalitesini de etkiler. Lipitler ve proteinler gibi az miktarda bulunan bileşenlerle etkileşimlerin de granüllerin molekül yapılarnnı etkilediği bildirilmiştir. Örneğin, mumlu nişastalar, normal ve yüksek amilozlu nişastalara göre daha az protein ve lipit içeriğine sahiptir (Singh vd., 2006; Shevkani vd., 2017; Kim vd., 2020; Li vd., 2020a). Normal ve yüksek amilozlu buğday nişastaları ile karşılaştırıldığında mumlu çeşitlerin daha küresel disk benzeri granül morfolojisi, daha küçük granül çap1 ve daha fazla kristal yap1 gösterdiği bildirilmiştir (Xu vd., 2020). Shevkani vd. (2017), mumlu ve normal mısır nişastalarının küresel ve poligonal-çokgen granül şekillerine sahipken, yüksek amilozlu mısır nişastasının uzun granül şeklinde olduğunu belirtmişlerdir. Kristallik özellĭgi, granüller içindeki amilopektin çift sarmallarının hiyerarșik organizasyonu sonucu ortaya çıkar. Amilopektinin dallanmış zincirleri birbirine dolanmış şekilde çift-sarmal yapıyı meydana getirir ve bu yapı sikıca kapanarak kristal kümeleşmeler oluşturur. Amiloz ise daha az düzenli olup amorf yapidan sorumludur. $\mathrm{Bu}$ sebeple, amiloz miktarı arttıkça nişasta kristalliği azalmaktadır. Yüksek amilozlu buğday nişastaları $\% 9$, mumlu buğday nişastaları ise $\% 40$ oranında kristallenme derecesine sahiptir. X-şsını difraktometresinden elde edilen sonuçlar, mumlu nişastaların, normal ve yüksek amilozlu nişastalardan daha kristal bir yapiya sahip olduğunu göstermiştir. Normal nişastaların ise yüksek amilozlu nişastalardan daha çok kristal yap1 sergilediği belirtilmiştir (Shevkani vd., 2017; Zhu., 2017; Nivelle vd., 2019).

\section{FARKLI NİŞASTA TİPLERINNIN FONKSIYYONEL ÖZELLIKKLERİ}

Nişastanın kritik sıcaklığın üzerinde yeterli su ile 1s1ttlmas1, jelatinizasyon olarak bilinen geri dönüşümsüz bir faz geçişine yol açmaktadır. Jelatinizasyon, önce hidrasyon ve amorf bölgenin su absorbe ederek şişmesi ile başlar. Sonra moleküler düzenin bozularak (hidrojen bağlarının kopması) kristal yapinın kaybolması (kristal bölgelerdeki amilopektinin ayrışması) meydana 
gelir. Bu da artan hidrasyon ve geri dönüşümsüz değişimlere, yani granüllerin şişmesine ve çözünmesine sebep olur (Li vd., 2020b). Jelleşme ise sulu ortamdaki dağınık-çözünmüş nişasta moleküllerinin soğuma ile birlikte üç boyutlu ağ yapılarını yeniden oluşturmaya başladığı süreç olarak karakterize edilebilir. Nişasta jeli, kovalent olmayan, genellikle hidrojen bağıyla stabilize edilmiş, moleküller arası çift sarmal oluşum olarak tanımlanabilir (Šárka ve Dvořáček, 2017). Kristal stabiliteye bağlı olan jelatinizasyon sicaklı̆̆1, amiloz içeriği ile değişen kristal yüzey serbest enerjisi ve amilopektinin polimerizasyon derecesi tarafindan olumsuz etkilenir (Nivelle vd., 2019). Normal nişastaların jelatinizasyonu genellikle düşük sıcaklık derecesi aralıklarında gerçekleşir. Amilopektinin moleküler boyutu ve dallanmış zincir uzunluğu, mumlu nişastaların jelatinizasyon davranışını ve ekmek hamurunun reolojik özelliklerini etkilemektedir (Šárka ve Dvořáček, 2017). Ayrıca, yüksek miktardaki amiloz varlığ1, yar1-kristal yapinın erime noktasını ve jelatinizasyon için gerekli enerjiyi düşürmektedir. $\mathrm{Bu}$ sebeple, mumlu nişastalar, normal ve yüksek amilozlu nişastalardan daha yüksek jelatinizasyon sicaklıkları ve endotermik entalpiye sahiptir (Shevkani vd., 2017; Li vd., 2020a). Kong vd. (2016) çeşitli arpalar ile ilgili yaptıkları bir çalışmada, amiloz içeriğinin, çirişlenme özellikleri ve jelatinizasyon entalpisi ile negatif korelasyona sahip olduğunu gözlemlemiştir. Nivelle vd. (2019), k1sa zincirli amilopektin yüksek miktarda içerildiğinde daha düşük, uzun zincirli amilopektin yüksek miktarda içerildiğinde ise daha yüksek jelatinizasyon sıcaklığı sergilendiğini rapor etmişlerdir. Mumlu nişastada amilopektin molekülleri uzun süreli 1sıtma ile büyük bir kısm1 granüllerden ayrllmakta ve sistem amilopektin çözeltisi haline dönüşmektedir. Öte yandan şişmiş granüller, mekanik bozulma viskozitesine (breakdown) oldukça duyarlıdır ve daha hızlı çözündüğü bildirilmiştir (Šárka ve Dvořáček, 2017). Normal nişastalara kıyasla, mumlu patates, mumlu misir ve mumlu arpa gibi amiloz içermeyen nişastalar, dar bir sıcaklık aralığında daha fazla su absorbe ederek şişme özelliği sergilerler. Ayrıca, nişasta granül yüzeyindeki protein ve lipit miktarı azaltılırsa, misır ve buğday nişastası granüllerinde su absorpsiyonu sonucu şişme oranının artabileceği ifade edilmiştir (Vamadevan ve Bertoft, 2018).

Çirişlenmiş nişastada soğuma ile birlikte amiloz ve amilopektin molekülleri arasında hidrojen bağları ile moleküler etkileşimler meydana gelmekte ve bu olay retrogradasyon olarak isimlendirilmektedir (Vamadevan ve Bertoft, 2018). Retrogradasyon, nişasta bazlı gıdaların raf ömrü kalitesini etkileyen başlıca faktördür, özellikle firrncilık ürünlerinde istenmeyen değişikliklere sebep olur (Mahmood vd., 2017). Retrogradasyona en güzel örnek ekmeğin bayatlaması verilebilir. Genel olarak, düşük amiloz içeriğinde yani mumlu nişastada, daha yüksek hamur viskozitesi ve düşük retrogradasyon eğilimi görülür (Hung vd., 2006). Nişasta çirişinin soğutulması ve depolanması sırasında, amiloz molekülleri çift sarmallar oluşturmak için yeniden birleşirken, amilopektinin dallanma noktaları kristal yapıyı oluşturmak için kendilerini kısmen düzenli yapılar halinde siralarlar. Amiloz, retrogradasyon hizinı artırmaktadır ve nişasta çirişinin soğutulması ve k1sa süreli depolanması sırasinda esnekliğin artmasından (ekmek kabuğunun bayatlamasi) büyük ölçüde sorumludur (Shevkani vd., 2017). Weil vd. (2020) normal tapiyoka (manyok) nişastası ile karşılaştırıldığında, mumlu tapiyoka nişastasının $130^{\circ} \mathrm{C}$ 'de daha yüksek bir çözünürlük, daha iyi berraklık ve daha düşük retrogradasyon eğilimine sahip olduğunu bildirmiştir. $\mathrm{Li}$ vd. (2020a), k1sa amilopektin zincirlerinin (PD=1324) retrogradasyonu teşvik ettiğini; uzun amilopektin zincirlerinin $(\mathrm{PD} \geq 37)$ daha düşük retrogradasyon eğilimi gösterdiğini belirtmişlerdir. Ekmeğin bayatlaması üzerine yapilan çalışmalarda, amiloz/amilopektin oranının nişasta retrogradasyonu üzerinde belirgin bir etkisi olduğu ve mumlu nişasta ilave edilmesinin retrogradasyonu geciktirebileceği ifade edilmiştir (Luo vd., 2020). Mumlu nişastalardaki yüksek amilopektin oranı, yapışkan ve sakızımsı bir doku sağlamaktadır (Mahmood vd., 2017). Yüksek amilozlu nişastada meydana gelen hızlı retrogradasyon, amilozun düşük molekül ağırlığ1 ile açıllanmaktadır. Depolama süresince amilopektinin tekrar agregat bir yapıya ulaşması ise daha yavaş seyretmektedir. Dolayısıyla, mumlu ve normal nişastalar, yüksek amilozlu 
nişastalardan daha yavaş ve daha az retrogradasyon eğilimindedir (Shevkani vd., 2017). Yapılan bir çalışmada, mumlu buğday nişastası depolama sırasında retrogradasyona karşı yükssek direnç gösterdiği bulunmuştur. Örneğin, 3 hafta depolama süresince, mumlu buğday nişastası jellerinin entalpisi bir miktar değişirken, normal buğday nişastası jellerinin entalpisinin iki kat arttı̆ı bildirilmiştir (Hung vd., 2006).

Amiloz/amilopektin oranının yanı sıra; amilopektinin yapıs1, lipitler ve lipitlerin amiloz ile kompleks oluşturması nişasta çirişlenme özelliklerini etkiler. Genel olarak, amiloz ve amiloz-lipit kompleksi miktarı ile pik viskozite değeri arasında ters orantı bulunmaktadır. Çünkü artan amiloz ve amiloz-lipit oranı, granüler sertliği ve bütünlügü artırarak çirişlenme sıcakliğını yükseltmekte ve pik viskoziteyi düşürmektedir. Bu sebeple, mumlu nişastalar, normal ve yüksek amilozlu nişastalardan daha yüksek pik viskozite ve kırrlma viskozitesi gösterirken, daha düşük çirişlenme sıcaklı̆̆ına sahip olduğu bildirilmiştir (Shevkani vd., 2017).

Hsieh vd. (2019), mumlu buğday, mısır, pirinç ve tapiyoka nişastaları normal muadillerine göre daha yüksek viskozite gösterirken, mumlu patates nişastasının normal patates nişastasından daha düşük viskozite gösterdiğini rapor etmişlerdir. Park vd. (2009)'nin yaptığ1 bir araştırmaya göre, patates nişastası, mumlu mısır nişastasından daha yüksek pik ve son viskoziteye sahip olduğu bulunmuştur. Mumlu misır nişastasının karışımdaki oranı arttıkça karışımın pik ve son viskozitesi azalmıştır. Patates nişastas $\left(67.9^{\circ} \mathrm{C}\right)$, mumlu misır nişastasından $\left(75.8^{\circ} \mathrm{C}\right)$ daha düşük jelatinizasyon derecesi göstermiştir. $\mathrm{Bu}$ yüzden, karışımın jelatinizasyon derecesinin, mumlu mısır nişastası oranı arttıkça arttı̆̆1 bildirilmiştir (Park vd., 2009). Yapılan çalışmalarda, mumlu buğday unlarinın, hamur hazırlama sirasinda normal buğday unlarına göre daha düşük son viskozite gösterdiği görülmektedir. Garimella Purna vd. (2015) tarafindan yapılan çalışmada, mumlu buğday nişastasının daha düşük jelatinizasyon sıcaklıklarına ve normal buğday nişastasından 2.5 kat daha fazla pik viskoziteye sahip olduğu bildirilmiştir. Ayrıca, mumlu buğday nişastasının, daha iyi bir kıvamlaştırma gücüne sahip modifiye nişasta ürünleri üretmek için iyi bir kaynak olduğu belirtilmiştir (Garimella Purna vd., 2015).

\section{FARKLI NISŞASTA TIIPLERİNİN ÜRÜN KALİTESİNE ETKILLERİ}

Amiloz/amilopektin oranı nişastanın fizikokimyasal özelliklerini belirlediğinden, buğday unundaki nişasta, erişte, ekmek, bisküvi gibi ürünlerin üretilmesi sirasindaki hamur özelliklerini ve son ürün kalitesini belirler. Mumlu nişastaların geliştirilmesi de sanayide kullanılan nişastanın bazı özelliklerinin iyileştirilmesini sağlamıştır (Šárka ve Dvořáček, 2017; Wang ve Shi, 2020). Mumlu buğdayda yüksek amilopektin düzeyinin, un ve nişasta özellikleri üzerinde önemli etkilere sahip olduğu, mumlu buğday ununun daha fazla su emdiği ve hamur gelişimi için daha kısa süre ve enerji gerektirdiği ifade edilmektedir. Mumlu buğday unu hamurunun karışturmaya karşı direncinin normal nişastadan daha az olduğu belirtilmiştir (Abdel-Aal vd., 2002). Mumlu buğday nişastasının normal buğday nişastasına göre bazı avantajlanı olmasına rağmen, gidalardaki uygulamalarını sinırlayan istenmeyen lifli hamur dokusu ve depolama sirasindaki retrogradasyonu gibi bazı dezavantajları vardır. Mumlu buğday nişastası hamurunun tekstürünü iyileştirmek için çapraz bağlama yapılabilir. Nişastanın propilen oksit ile modifikasyonu olan hidroksipropilasyon yönteminin nişastadaki hidroksil gruplarının yerini alarak mumlu buğday nişastasının işlevselliğini artırabileceği bildirilmiştir. Buna göre, normal ve mumlu buğday ve mumlu mısır nişastalarının \%3-9 oranında hidroksipropilasyonu sonucunda molar sübstitüsyon oranındaki artışla birlikte jelatinizasyon sıcaklığı ve entalpi değerlerinin azaldığ depolama süresince retrogradasyon eğiliminin azaldığ1 ifade edilmiştir (Wang ve Shi, 2020).

Choi ve Baik (2014) tarafindan yapılan çalışmada, farklı nişasta tiplerine ve tane sertliğine sahip 20 adet buğday unundan veya nişastalarından pandispanya keki yapılmış, normal ve mumlu nişasta karışımındaki amiloz içeriği azaldıkça kek hacminin de azaldığ 1 ve kek hacminin çirişlenme (pasting) özellikleri ile önemli derecede ilişkili olduğu belirtilmiştir. Hung vd. (2007) tarafindan, 
buğday nişastasındaki amilopektinin, su absorbe ederek nişasta granüllerinin şişmesine ve çirişlenmesine katkı sağlarken, amiloz ve lipitlerin bu aşamalanı geciktirmeye çalışı̆̆̆ bildirilmiştir. Daha yüksek sicakliklarda $\left(>50^{\circ} \mathrm{C}\right)$, mumlu buğday nişastasının şişme gücü hızla artmış, normal ve yükssek amilozlu buğday nişastalarından daha fazla gerçekleşmiştir. Bu sebeple, mumlu buğday nişastası 1sıtma sırasında suyun büyük miktarını absorbe ederek yüksek şişme gücüne ve viskozitede bir artışa sebep olmuş, $70^{\circ} \mathrm{C}^{\prime}$ den daha fazla sıcaklıklarda 1sıttldığında sudaki çözünürlüğü artmıştır. Yüksek amilozlu buğday nişastasının ise $50^{\circ} \mathrm{C}^{\prime}$ den düşük sicaklıklarda isıtıldığında normal ve mumlu buğday nişastasından daha yüksek şişme gücüne sahip olduğu ifade edilmiştir (Hung vd., 2007).

Mumlu nişastaların, ekmeğin bayatlamasını yavaşlatmak için kullanılabileceği belirtilmiştir. Düşük amiloz içeriği ekmeği başlangıçta çok yumuşak hale getirmekte ve bayatlama sirasinda amilopektin retrogradasyonunun çok sert bir ekmek yapıs1 vermediği ve amilopektin retrogradasyonunun su içeriğine bağlı olduğu rapor edilmiştir (Eliasson vd., 2013). Mumlu buğday ununun firlnclltk ürünlerinin hacmini, nem tutma kapasitesini, yumuşaklı̆̆ını ve raf ömrünü artırdığı, ayrıca bu ürünlerde yağ miktarını azalttığ1 ifade edilmiştir. Kahvaltılık misır gevrekleri, krakerler ve tuzlu atışırmalıklar gibi kuru tahıl ürünlerinde, ürünün 1sırılmasını kolaylaştırmak ve ufalanabilirliğini artırmak amaciyla mumlu buğday unu eklendiği belirtilmiştir (Garimella Purna vd., 2015). Witczak vd. (2019) mumlu nişastanın nişasta temelli glutensiz ekmek yapımı ve bayatlamasinın geciktirilmesi üzerine etkisini incelemişlerdir. Mısır/patates nişastaları karışımının \%10'unun mumlu nişasta karışımı (mumlu mısır/mumlu patates nişastası) ile yer değiştirilmesi, ekmek hacminde optimum bir artışa, ekmek içi yapısında çok az bir değişime sebep olmuştur. Mumlu nişasta karışımının \%10-15 oranlarında eklenmesi ile ekmek içi tekstüründe olumlu bir etki, ekmek sertliği ve çiğnenebilirlik özelliğinde bir azalma fakat depolama süresince bir artma ve amilopektin retrogradasyon entalpisinde bir azalma tespit etmişlerdir. Singh vd. (2006) tarafindan, mumlu mısır nişastalarının şişme gücünün (30.2-39.2 $\mathrm{g} / \mathrm{g})$, amilotip misır nişastası $(7.8 \mathrm{~g} / \mathrm{g})$ ve normal misır nişastalarından (11.6-15.2 g/g) daha yüksek olduğu saptanmıştır. Aynı çalışmada, normal nişastalar ve amilotip nişastanın amiloz içeriği sirasiyla \%29.5-32.6 ve \%41 olarak belirlenirken; amilotip, normal ve mumlu nişastalarının DSC'de ölçülen faz geçiş sıcaklık aralıklanı $\left(T_{0}-T_{c}\right)$ sırasıyla; $60.5-76.1, \quad 63.5-76.3$ ve $64.4-81.3^{\circ} \mathrm{C}$ olarak bulunmuştur. Mumlu buğday unundan yapılan ekmeğin kalitesinin düşük ve tüketiciler tarafindan kabul görmediği bildirilmiştir. Çünkü mumlu buğday unundan yapılan ekmeğin fazla miktarda gözenek ve zayıf ekmek içi yapısına sahip olduğu ve depolama ile birlikte bu yapının çökerek yapışkan bir ekmek içinin oluştuğu bildirilmiştir. Mumlu buğday unundan hazırlanan eriştelerin, normal nişastalı buğday unundan yapilan eriştelere göre pişirmeden sonra oldukça yapışkan ve yumuşak olduğu, yüzeyinde çok sayıda kabarcığın meydana geldiği ve kızartma sırasında birbirine yapıştı̆̆ ve aşır1 yağ absorbe ettiği ifade edilmiştir (Jung vd., 2015). Mumlu buğday ununun farklı buğday kepekleri ile \%12.5-37.5 oranında katkilandiktan sonra yapilan ekstrüzyon işlemiyle üretilen ekstrüde ürünlerin fiziksel ve çirişlenme özelliklerinin oldukça farklilık gösterdiği ifade edilmiştir (Fleischman vd., 2016). Hogg vd. (2015) tarafindan, makarna yapımında yüksek amilozlu makarnalık buğdayın kullanılmasının, aşırı pişmeye karşı daha dirençli ve sert makarna verdiği, son ürün kalitesini ve bununla birlikte beslenme kalitesini de artırdığ bildirilmiştir. Yüksek amilozlu makarnanın, bağırsak ve kardiyovasküler hastalıkları önleyen ve glisemik tepkiyi azaltan enzime dirençli nişasta bakımından zengin olduğu rapor edilmiştir. Liu vd. (2018) tarafindan yapılan bir çalışmada; peynirde daha homojen bir yapinın elde edilmesi amaciyla sodyum kazeinatın yerine mumlu pirinç nişastasının kullanılması ve mumlu pirinç nişastasının peynirlerin yapısı üzerindeki etkisi araştırılmış, mumlu pirinç nişastasının peynirlerin olgunlaşmasını, homojenliğini, sertliğini, kokusunun keskinliğini ve rengini iyileştirdiği gösterilmiştir. 


\section{FARKLI NIŞASTA TİPLERİNINN SİNDİRİLEBİLİRLİK ÖZELLİKLERİ}

Nişastanın sindirimi sonucu, örneğin Tip II diyabet, obezite ve kardiyovasküler hastalıklar gibi metabolik hastalıkları tetikleyen glukoz salınımı gerçekleşmektedir. Dolayısıyla, insanların sağlı̆̆ını korumak için nişasta sindirilebilirliğinin düzenlenmesine (sindirim oranı ve derecesi vb.) büyük ölçüde dikkat edilmelidir (Qiao vd., 2017). Nişastalar sindirilebilirlik özelliklerine göre hızlı sindirilebilir nişasta (HSN), yavaş sindirilebilir nişasta (YSN) ve enzime dirençli nişasta (EDN) olmak üzere üçe ayrilır. İnsan vücudunda, HSN, yemek sonrasi ilk 20 dakikadaki kan glukoz seviyesindeki artışan sorumlu olup, tüketilen gıdanın glisemik indeks (GI) değeri ile bağlantılıdır. HSN'nın, diyabet, obezite ve kardiyovasküler hastalıklar gibi birçok kronik hastalıklara sebep olan hiper-glisemiye yol açtığ bildirilmiştir. YSN, ince bağırsakta yavaşça sindirilen, 120 dakikaya kadar kan glukoz seviyesini yükseltmeyen nişasta tipi olup, glisemik tepkiyi ve hiper-lipidemiyi azalttı̆̆ performans1 ve tokluğu etkili bir şekilde düzenlediği ifade edilmiştir. EDN, ince bağırsakta amilolitik enzimlerin sindirimine direnç gösteren ve kalın bağırsaktaki bakteriler tarafindan kısmen veya tamamen fermente edilerek kısa zincirli yağ asitleri gibi önemli son ürünler meydana getiren nişasta olarak tanımlanır. Ayrıca, EDN, ülseratif kolit ve kolon kanserinin önlenmesi, glisemik tepkiyi düşürmesi, kolesterol seviyesi, safra taş1 oluşumu, Tip II diyabet ve obezitenin önlenmesi ve mineral emilimini artırması gibi fizyolojik yararlara sahiptir ve probiyotiklerin gelişmesini teşvik ettiği için iyi bir prebiyotiktir. Bu sebeple, son yllardaki beslenme rehberleri, HSN tüketimini azaltmayı ve insan sağlğ̆ına fizyolojik yararlar sağlayan EDN tüketimini artırmayı önermektedir (Lu ve Baik, 2015; Ahmed vd. 2016; Sui vd., 2017; Zhong vd., 2018; Yoo vd., 2018; Situ vd., 2019; Kim vd., 2020; Zhang vd., 2020; Xu vd., 2020).

Nişastanın sindirimi; kristal yapının düzenliliăgi, amiloz ve amilopektinin moleküler yapıları, dallanmış yapının yoğunluğu ve amiloz miktarından büyük ölçüde etkilenmektedir. Amiloz/amilopektin oranı, nişasta sindirilebilirliğini etkileyen ana faktörlerden birisidir. Mumlu nişastalar genellikle hızlı sindirilebilir nişastalardır. Yüksek amilozlu nişastalar ise yavaş sindirilir ve EDN kaynağıdırlar. Yüksek amilozlu nişastalar, yüzeyindeki porlar sebebi ile daha yavaş hidrolize edilirken, mumlu nişastaların iç taraflarındaki porlar sebebi ile daha yüksek oranlarda sindirildiği belirtilmiştir. In vitro sindirim sonuçları, EDN miktarının, yüksek amiloz içeriği, tek heliksli yapı ve yüzey kısa-sıralı yapının miktarı ile arttığını göstermiştir. EDN'nin, tek heliksli yapıdan ve 1324 polimerizasyon dereceli kristalitlerden oluştuğu bildirilmiştir. YSN ise tek heliksli yapıdan oluşurken, hızlı sindirilebilir nişastanın düzensiz amorf bölgelerden meydana geldiği ifade edilmiştir. Araştırmalar amilopektinin amiloza göre daha hızlı sindirildiğini göstermiştir. Mumlu nişastaların amilolitik aktiviteye hassasiyeti, yapısındaki amilopektin molekülünün yüzey alanının oldukça fazla olmasından ileri gelmektedir. Bununla birlikte uzun amiloz zincirinin, nişasta sindirilebilirliğini artırdığı rapor edilmiştir. Kısa çift sarmallı normal nişastalar, amilolitik aktiviteye oldukça hassastır ve yüksek miktarda hızlı ve yavaş sindirilebilir nişasta içerirler. Ayrıca, jelatinize mumlu nişastanın enzimatik hidrolize hassasiyetinin, normal ve yüksek amilozlu nişastalara göre daha fazla olduğu ifade edilmiştir. Bununla birlikte nişastaya bağlı protein ve lipitlerin nişasta sindirilebilirliğini azalttı̆̆ çeşitli çalışmalarda belirtilmiştir (Svihus vd., 2005; Shevkani vd., 2017; Situ vd., 2019; Xu vd., 2020). Yapılan bir çalışmada, yüksek amilozlu durum buğdayından yapılan makarnanın besinsel kalitesinin iyileştiği ve uzun süre pişmeye karşı direncinin arttı̆g tespit edilmiştir (Hogg vd., 2015). Yüksek amilozlu nişastanın, gıdalardaki lif içeriğini veya EDN içeriğini artırarak Tip II diyabet ve obezite gibi metabolik bozuklukları azalttığı, bağışıklık sistemi ve kolonik hastalıklanı iyileştirdiği rapor edilmiştir (Li vd., 2020). Amilozun sindirimi amilopektine göre daha yavaştır ve glukozun kandaki dolaşımı da daha yavaş seyreder. Amilozun ince bağırsaktaki sindiriminin tam olarak tamamlanmadığ1 ve amiloz ile zengin nişastaların sindirime daha fazla direnç gösterdiği bildirilmiştir. Yüksek amilozlu nişastaların sindirime olan direnci çeşitli 
mekanizmalar ile açıklanmıstır, bunlar: a. nişasta granüllerinin, amilozun amilopektin kristalleri arasında sarmalanması sebebiyle kapalı bir bütünlük arz etmesi; b. fazla miktardaki amilozlipit kompleksi sayesinde sulu ortamda 1sitma süresince nişasta granüllerinin sınırlı düzeyde şişmesi; c. jelatinize nişastanın depolama süresince retrogradasyonu sonucu muntazam kristal yapılara dönüşmesidir. Hem insan hem de hayvan deneylerinde bulunan sonuçlara göre, diyete yüksek amilozlu misır nişastası eklenmesinin, yağ birikimini azalttığ1 veya vücuttaki yağ dağılımını değiştirdiği rapor edilmiştir. Yüksek amilozlu misır nişastası ile beslenmenin ayrica, serum kolesterol, serum trigliserit ve hepatik trigliserit düzeylerini düşürdüğü ve adipoz dokuda yağlanmayı engellediği, obezite ve ilgili kronik hastalıkların ortaya çıkışının azaltabildiği bildirilmiştir (Ai ve Jane, 2016). Probiyotikler (Clostridium butyricum veya Bifidobacterium lactis) ile kombinasyon halinde kullanılan yüksek amilozlu mısır nişastasının, kolon kanserinin veya onun varsayılan öncü lezyonlarının gelişimini etkin bir şekilde inhibe ettiğgi bildirilmiştir. Ayrıca, hayvan deneyleri ile ilgili yapılan bazı çalışmalar, yüksek amilozlu mısır nişastasının gıdalara eklenmesinin, $\mathrm{Ca}, \mathrm{Mg}, \mathrm{Zn}, \mathrm{Fe}$ ve $\mathrm{Cu}$ dâhil olmak üzere önemli minerallerin emilimini belirgin şekilde artırdığı ifade edilmiştir. Minerallerin gelişmiş emiliminin, yükssek amilozlu mısır nişastasının fermantasyonu ile birlikte meydana gelen kısa zincirli yağ asitlerinin üretilmesi ve daha düşük bir $\mathrm{pH}^{\prime}$ da bağırsak ve kolondaki artan çözünürlükleri ile ilgili olduğu ifade edilmiştir (Ai ve Jane, 2016).

Nişasta granülleri, özel koşullar altında pullulanaz ve izoamilaz gibi enzimlerle $\alpha-1,6$ bağlı dallanma noktalarnndan hidroliz edilebilirler. Mumlu nişastanın tamamen dallanma noktalarından ayrılması ile her nişasta kaynağının yapısına bağlı olarak, yaklaşık 6-100 arasında değişen zincir uzunluklarına sahip doğrusal dekstrin/amiloz zincirleri meydana gelebilmektedir. Bir dizi patentli gıdada ve g1da dişı üründe dallanma noktaları hidroliz edilerek çeşitli nişasta tipleri ortaya çıkarılmıştır. Örneğin bu nişastaların EDN kaynağı, yağ ikame maddesi, opaklaştırıcı madde, içeceklerde renklendirici ve kozmetikte nemlendirici ve dokusal özellikleri iyileştiren ajan olarak kullanılabileceği ifade edilmiştir. Dallanma noktalarından hidrolize olmuş nişastalardan EDN ve YSN üretimi ile ilgili güncel çalışmalar halen sürmektedir (Precha-Atsawanan vd., 2018).

\section{YÜKSEK AMİLOZLU NİŞASTADAN DİRENÇLİ NİŞASTA ÜRETİMİ}

Enzime dirençli nişasta (EDN) beş farklı tipte bulunur: $\mathrm{EDN}_{1}$ : kısmen veya tamamen öğütülmüş tohumlar gibi sindirilemeyen bir matris içinde fiziksel olarak tutulmuş, erişilemeyen nişasta; $\mathrm{EDN}_{2}$ : doğal granül formundaki nişasta; $\mathrm{EDN}_{3}$ : 1sıttlmış daha sonra soğutulmuş retrograde nişasta; $\mathrm{EDN}_{4}$ : kimyasal olarak modifiye edilmiş nişasta; $\mathrm{EDN}_{5}$ : amiloz sarmal yapısında lipit bileşeni ile kompleks yapmış nişasta olarak karakterize edilmektedir (Masatcioglu vd., 2017). EDN 2 , patates, yeşil muz, yüksek amilozlu mısır nişastası ve bazı baklagillerde bulunur. $\mathrm{Bu}$ nişastalarda, uzun zincirli dallanmış amilopektin molekülü oransal olarak daha fazla bulunur. Bu ise esnek olmayan bölgelerin ve zaylf noktaların meydana gelmesine yol açmakta ve böylece doğal nişasta granüllerini enzimatik hidrolize karşı dirençli hale getirmektedir. Nişastadaki yüksek miktardaki ve uzun amiloz içeriği genel olarak yüksek miktardaki EDN içeriği ile ilişkilendirilmekte olup, sslah çalışmaları yoluyla amiloz seviyesinin yükseltilmesi ile endojen EDN miktarının arturlmasinın olası bir yöntem olduğu ifade edilmiştir. İki metodun başarı ile kullanılabileceği belirtilmiştir, bunlar: yüksek amiloz üretimini sağlayan genlere sahip mutantlar ile melezleme ve nişasta sentezinde dallanmadan sorumlu enzimlerin inhibisyonu şeklinde açılanmıştır (Dupuis vd., 2014). Retrograde amiloz, EDN 3 'nin bir formudur ve çok yavaş sindirildiğinden besinsel lif gibi davrandığı belirtilmiştir. Amiloz amilopektine göre daha kısa sürede retrograde olabilmektedir. Bu sebeple; amiloz/amilopektin oranı ne kadar yüksekse retrogradasyon o kadar hızlı gerçekleşmekte ve amiloz bakımından zengin olan nişastalardan daha fazla EDN üretilmektedir. Mumlu, normal ve yüksek amilozlu misır nişastaları, nişasta yapılarındaki düzenliliği azaltmak için su ile karışırıldıktan sonra ekstrüzyon işlemine tabi tutulmuş ve yalnızca yüksek amilozlu ekstrüde mısır nişastasının 
sindirime karşı direncinin en fazla olduğu görülmüss, uzun zincir yapısına sahip amiloz molekülünün bunda önemli rol oynadığ belirtilmiştir (Zhang vd., 2015). Yüksek amilozlu buğdayların besinsel lif içeriklerinin EDN miktarlar1 sayesinde 10 kat artması ile kronik hastalıkların önlenmesi için gerekli sağlıklı gidaların üretilmesinde kullanilabileceği rapor edilmiştir (Bird ve Regina, 2018).

\section{SONUÇ}

Mumlu ve yüksek amilozlu tahıl nişastaları, tahıl genomlarında bazı modifikasyonlar yapilarak geliştirilmiştir. Mumlu ve yüksek amilozlu tahıl nişastaları son ürünün tekstürünü ve kalitesini istenilen şekilde iyileştirmek için gıda ürünlerinde tercih edilmektedir. Bu nişastalar, çeşitli fizyolojik etkilere sahip besinsel lif ve enzime dirençli nişasta kaynakları olarak son y1llarda önem kazanmaya başlamışır. Yüksek amilozlu nişasta, prebiyotik özelliğe sahip EDN üretiminde önemli bir kaynakttr. Yüksek amilozlu tahıl nişastaları ile beslenmenin kronik hastalıkların önlenmesinde önemli olduğu vurgulanmıştr. Amiloz biyosentezinden sorumlu GBSS genlerinin baskılanması ile sentezlenen mumlu nişasta, yüksek düzeyde dallanmış ve kristal yapıya sahiptir. Bu yapısal özellikler mumlu buğday nişastasına, yüksek şişme gücü ve çiriş viskozitesi ve fakat düşük çirişlenme sicaklığ1, düşük retrogradasyon eğilimi yani katulaşma viskozitesi gibi fonksiyonel özellikler kazandırmaktadır. Bundan dolayı, gida ürünlerinde normal buğday nişastasının yerine mumlu buğday nişastasının kullanımı ile daha geç bayatlayan ve uzun raf ömrüne sahip firıncllı ürünlerinin üretilebileceği çeşitli çalışmalarda belirtilmiştir.

\section{ÇIKAR ÇATIŞMASI BEYANI}

Yazarların, başka kişiler ve/veya kurumlar ile çıkar çatışması bulunmamaktadır.

\section{YAZAR KATKILARI}

EY, MTM ve BC derlemeyi birlikte planlamıs, yazmış ve son halini onaylamışlardır.

\section{KAYNAKLAR}

Abdel-Aal, E.-S.M., Huck, P., Chibbar, R.N., Han, H.L., Demeke, T. (2002). Physicochemical and structural characteristics of flours and starches from waxy and nonwaxy wheats. Cereal Chem, 79(3): 458-464.

Ahmed, Z., Tetlow, I.J., Falk, D.E., Liu, Q., Emes, M.J. (2016). Resistant starch content is related to granule size in barley. Cereal Chem, 93(6): 618-630.

Ai, Y., Jane, J-I. (2016). Macronutrients in corn and human nutrition. Compr Rev Food Sci Food Saf, 15(3): 581-598.

Bird, A.R., Regina, A. (2018). High amylose wheat: A platform for delivering human health benefits. J Cereal Sci, 82: 99-105.

Choi, H.-W., Baik, B.-K. (2014). Significance of starch properties and quantity on sponge cake volume. Cereal Chem, 91(3): 280-285.

Dupuis, J.H., Liu, Q., Yada, R.Y. (2014). Methodologies for increasing the resistant starch content of food starches: A review. Compr Rev Food Sci Food Saf, 13(6): 1219-1234.

Eliasson, A.-C., Bergenstal, B., Nilsson, L., Sjöö, M. (2013). From molecules to products: Some aspects of structure-function relationships in cereal starches. Cereal Chem, 90(4): 326-334.

Fleischman, E.F., Kowalski, R.J., Morris, C.F., Nguyen, T., Li, C., Ganjyal, G., Ross, C.F. (2016). Physical, textural, and antioxidant properties of extruded waxy wheat flour snack supplemented with several varieties of bran. J Food Sci, 81(11): E2726-E2733.

Garimella Purna, S.K., Shi, Y.-C., Guan, L., Wilson, J.D., Graybosch, R.A. (2015). Factors governing pasting properties of waxy wheat flours. Cereal Chem, 92(5): 529-535.

Graybosch, R.A., Ohm, J.-B., Dykes, L. (2016). Observations on the quality characteristics of waxy (amylose-free) winter wheats. Cereal Chem, 93(6): 599-604.

Hogg, A.C., Martin, J.M., Manthey, F.A., Giroux, M.J. (2015). Nutritional and quality traits of pasta made from SSIIa null high-amylose durum wheat. Cereal Chem, 92(4): 395-400. 
Hsieh, C.-F., Liu, W., Whaley, J. K., Shi, Y.-C. (2019). Structure and functional properties of waxy starches. Food Hydrocoll, 94: 238-254.

Hung, P.V., Maeda, T., Morita, N. (2006). Waxy and high-amylose wheat starches and flourscharacteristics, functionality and application. Trends Food Sci Tecbnol, 17(8): 448-456.

Hung, P.V., Maeda, T., Morita, N. (2007). Study on physicochemical characteristics of waxy and high amylose wheat starches in comparison with normal wheat starch. Starke, 59(3-4): 125-131.

Inokuma, T., Vrinten, P., Shimbata, T., Sunohara, A., Ito, H., Saito, M., Taniguchi, Y., Nakamura, T. (2016). Using the hexaploid nature of wheat to create variability in starch characteristics. J Agric Food Chem, 64(4): 941-947.

Jung, T.-H., Kim J.Y., Baik, B.-K., Park, C.S. (2015). Physicochemical and thermal characteristics of starch isolated from a waxy wheat genotype exhibiting partial expression of wx proteins. Cereal Chem, 92(1): 14-21.

Kim, H.R., Jun Choi, S., Choi, H.-D., Park, C.-S., Moon, T.W. (2020). Amylosucrase-modified waxy potato starches recrystallized with amylose: the role of amylopectin chain length in formation of low-digestible fractions. Food Chem, 318: 126490.

Kong, X., Kasapis, S., Zhu, P., Sui, Z., Bao, J., Corke, H. (2016). Physicochemical and structural characteristics of starches from Chinese hull-less barley cultivars. Int J Food Sci Technol, 51(2): 509518.

Lee, H., Kim, H.-S. (2020). Pasting and paste properties of waxy rice starch as affected by hydroxypropyl methylcellulose and its viscosity. Int J Biol Macromol, 153: 1202-1210.

Li, C., Zhou, D., Fan, T., Wang, M., Zhu, M., Ding, J.,Zhu, X., Guo, W., Shi, Y.-C. (2020a). Structure and physicochemical properties of two waxy wheat starches. Food Chem, 318, 126492.

Li, C., Dhital, S., Gilbert, R. G., Gidley, M. J. (2020b). High-amylose wheat starch: structural basis for water absorption and pasting properties. Carbobydr Polym, 245, 116557.
Li, H., Dhital, S., Flanagan, B. M., Mata, J., Gilbert, E. P., Gidley, M. J. (2020). High-amylose wheat and maize starches have distinctly different granule organization and annealing behaviour: A key role for chain mobility. Food Hydrocoll, 105, 105820 .

Liu, L., Zhang, H., Li, X., Han, X., Qu, X., Chen, P., Wang, H., Wang, L. (2018). Effect of waxy rice starch on textural and microstructural properties of microwave-puffed cheese chips. Int J Dairy Technol, 71(2): 501-511.

Lu, L., Baik, B.-K. (2015). Starch characteristics influencing resistant starch content of cooked buckwheat groats. Cereal Chem, 92(1): 65-72.

Luo, Y., Xiao, Y., Shen, M., Wen, H., Ren, Y., Yang, J., Han X, Xie, J. (2020). Effect of Mesona chinensis polysaccharide on the retrogradation properties of maize and waxy maize starches during storage. Food Hydrocoll, 101, 105538.

Magallanes-Cruz, P.A., Flores-Silva, P.C., BelloPerez L.A. (2017). Starch structure influences its digestibility: A Review. J Food Sci, 82(9): 20162023.

Mahmood, K., Kamilah, H., Shang, P.L., Sulaiman, S., Ariffin, F., Alias, A.K. (2017). A review: Interaction of starch/non-starch hydrocolloid blending and the recent food applications. Food Biosci, 19: 110-120.

Masatcioglu, T.M., Sumer, Z., Koksel, H. (2017). An innovative approach for significantly increasing enzyme resistant starch type 3 content in high amylose starches by using extrusion. $J$ Cereal Sci, 74: 95-102.

Nivelle, M.A., Remmerie, E., Bosmans, G.M., Vrinten, P., Nakamura, T., Delcour, J.A. (2019). Amylose and amylopectin functionality during baking and cooling of bread prepared from flour of wheat containing unusual starches: A temperature-controlled time domain 1H NMR study. Food Chem, 295: 110-119.

Park, E.Y., Kim, H.N., Kim, J.Y., Lim, S.T. (2009). Pasting properties of potato starch and waxy maize starch mixtures. Stärke, 61(6): 352357. 
Precha-Atsawanan, S., Puncha-Arnon, S., Wandee, Y., Uttapap, D., Puttanlek, C., Rungsardthong, V. (2018) Physicochemical properties of partially debranched waxy rice starch. Food Hydrocoll, 79: 71-80.

Qiao, D., Xie, F., Zhang, B., Zou, W., Zhao, S., Niu, M., Lv, R., Cheng, Q., Jiang, F., Zhu, J. (2017). A further understanding of the multi-scale supramolecular structure and digestion rate of waxy starch. Food Hydrocoll, 65: 24-34.

Samarakoon, E. R. J., Waduge, R., Liu, Q., Shahidi, F., Banoub, J. H. (2020). Impact of annealing on the hierarchical structure and physicochemical properties of waxy starches of different botanical origins. Food Chem, 303, 125344.

Šárka, E., Dvořáček, V. (2017). Waxy starch as a perspective raw material (a review). Food Hydrocoll, 69: 402-409.

Shevkani, K., Singh, N., Bajaj, R., Kaur, A. (2017). Wheat starch production, structure, functionality and applications-A review. Int J Food Sci Technol, 52(1): 38-58.

Singh, N., Inouchi, N., Nishinari, K. (2006). Structural, thermal and viscoelastic characteristics of starches separated from normal, sugary and waxy maize. Food Hydrocoll, 20(6): 923-935.

Situ, W., Song, X., Luo, S., Yang, J. (2019). Digestibility and structures of vinasse starches with different types of raw rice and fermented leaven. Food Chem, 294: 96-103.

Su, C., Saleh, A. S. M., Zhang, B., Zhao, K., Ge, X., Zhang, Q., Li, W. (2020). Changes in structural, physicochemical, and digestive properties of normal and waxy wheat starch during repeated and continuous annealing. Carbohydr Polym, 247, 116675.

Sui, Z., Yao, T., Ye, X., Bao, J., Kong, X., Wu, Y. (2017). Physicochemical properties and starch digestibility of in-kernel eat-moisture-treated waxy, low-, and high-amylose rice starch. Stärke, 69(7-8): 1600164.

Svihus, B., Uhlen, A.K., Harstad, O.M. (2005). Effect of starch granule structure, associated components and processing on nutritive value of cereal starch: A review. Anim Feed Sci Technol, 122(3-4): 303-320.

Vamadevan, V., Bertoft, E. (2018). Impact of different structural types of amylopectin on retrogradation. Food Hydrocoll, 80: 88-96.

Wang, W., Shi, Y.-C. (2020). Gelatinization, pasting and retrogradation properties of hydroxypropylated normal wheat, waxy wheat, and waxy maize starches. Food Hydrocoll, 106, 105910.

Weil, W., Weil, R. C., Keawsompong, S., Sriroth, K., Seib, P. A., Shi, Y.-C. (2020). Pyrodextrin from waxy and normal tapioca starches: Physicochemical properties. Food Hydrocoll, 104, 105745.

Witczak, M., Korus, J., Ziobro, R., Juszczak, L. (2019). Waxy starch as dough component and anti-staling agent in gluten-free bread. LWT-Food Sci Technol, 99: 476-482.

Xu, J., Chen, L., Guo, X., Liang, Y., Xie, F. (2020). Understanding the multi-scale structure and digestibility of different waxy maize starches. Int J Biol Macromol, 144: 252-258.

Yoo, H.J., Kim, H.R., Choi, S.J., Park, C.-S., Moon, T.W. (2018). Characterisation of lowdigestible starch fractions isolated from amylosucrase-modified waxy corn starch. Int $J$ Food Sci Technol, 53(3): 557-563.

Zhang, B., Dhital, S., Flanagan, B.M., Luckman, P., Halley, P.J., Gidley, M.J. (2015). Extrusion induced low-order starch matrices: Enzymic hydrolysis and structure. Carbohydr Polym, 134, 485-496.

Zhang, Y., Gladden, I., Guo, J., Tan, L., Kong, L. (2020). Enzymatic digestion of amylose and high amylose maize starch inclusion complexes with alkyl gallates. Food Hydrocoll, 108, 106009.

Zhong, Y., Zhu, H., Liang, W., Li, X., Liu, L., Zhang, X., Yue, H., Xue, J., Liu, X., Guo, D. (2018). High-amylose starch as a new ingredient to balance nutrition and texture of food. J Cereal Sci, 81: 8-14.

Zhu, F. (2017). Barley starch: Composition, structure, properties, and modifications. Compr Rev Food Sci Food Saf, 16(4): 558-579. 